\title{
Marek Potyraj*
}

Uniwersytet Szczeciński

\section{PROCES INWESTYCYJNO-BUDOWLANY W UJĘCIU ADMINISTRACYJNOPRAWNYM}

\section{Streszczenie}

Działalność inwestycyjno-budowlana uregulowana jest zasadniczo przez przepisy administracyjne, gdyż w procesie budowlanym czynności administracyjnoprawne mają charakter dominujący. Przepisy wielu aktów normatywnych regulują sprawy inwestycji budowlanych. Są wśród nich zarówno takie, których przedmiotem jest wyłącznie problematyka inwestycyjna, jak i takie, które znajdują zastosowanie nie tylko w odniesieniu do inwestycji budowlanych. Z regulacji prawa budowlanego wynika, że ustawodawca założył konieczność wymuszania pewnych zachowań w procesie budowlanym.

$\mathrm{W}$ pracy przedstawiono zawarte $\mathrm{w}$ aktach prawnych normujących inwestycyjno-budowlaną aktywność człowieka ograniczenia działań inwestycyjnych, które mogą być podejmowane na poszczególnych etapach procesu budowlanego. Realizacja inwestycji budowlanych możliwa jest wyłącznie na obszarze o określonym przeznaczeniu. W związku z tym, w pierwszej kolejności opisano zagadnienia związane z przeznaczeniem terenu pod inwestycję. Następnie omówiono zagadnienia związane ze zgodą na podjęcie robót budowlanych, użytkowaniem obiektu budowlanego, zmianą sposobu użytkowania obiektu, a także rozbiórką obiektu budowlanego.

Słowa kluczowe: proces inwestycyjny, roboty budowlane, proces inwestycyjno-budowlany

\footnotetext{
*Adres e-mail: marekp1@poczta.onet.eu
} 


\section{Zagadnienia ogólne}

Celem opracowania jest przybliżenie zasad obowiązujących w uregulowaniach prawnych dotyczących procesu inwestycyjno-budowlanego.

Proces inwestycyjny stanowi jedną z podstawowych aktywności człowieka. Jego celem jest zmiana sposobu zagospodarowania terenu, która może polegać na budowie, przebudowie, nadbudowie lub też zmianie sposobu użytkowania obiektu.

Pojęcie procesu inwestycyjnego nie zostało zdefiniowane przez ustawodawcę, jednak wiele aktów normatywnych posługuje się pojęciem inwestycji ${ }^{1}$, między innymi: inwestycje w zakresie dróg publicznych, inwestycje w zakresie budowli przeciwpowodziowych, inwestycje infrastruktury kolejowej czy inwestycje celu publicznego.

Proces to inaczej postępowanie lub też zdarzenia, które mają występować po sobie. Inwestycją są nakłady gospodarcze, których celem jest stworzenie nowych lub powiększenie już istniejących środków trwałych ${ }^{2}$. Poprzez inwestycję budowlaną należy rozumieć wszelką działalność człowieka, której celem jest zmiana sposobu zagospodarowania terenu, polegającą bądź na budowie lub wykonywaniu innych robót budowlanych, bądź na zmianie sposobu użytkowania obiektu budowlanego lub jego części³.

W procesie inwestycyjno-budowlanym wyróżnić można następujące etapy: określenie przeznaczenia terenu, sposób jego zagospodarowania, uzyskanie pozwolenia na prowadzenie robót budowlanych oraz ich wykonywanie, użytkowanie obiektu, zmiana sposobu użytkowania, rozbiórka obiektu budowlanego.

Przepisy wielu aktów normatywnych regulują sprawy inwestycji budowlanych. Są wśród nich zarówno takie, których przedmiotem jest wyłącznie problematyka inwestycyjna, jak i takie, które znajdują zastosowanie nie tylko w odniesieniu do inwestycji budowlanych ${ }^{4}$.

${ }^{1}$ Ustawodawca w Ustawie z dnia 29 września 1994 r. o rachunkowości (t.j. Dz. U. z 2013 r., poz. $330 \mathrm{z}$ późn. zm.) zdefiniował inwestycje jako aktywa posiadane przez jednostkę w celu osiągnięcia z nich korzyści ekonomicznych wynikających z przyrostu wartości tych aktywów, uzyskania przychodów w formie odsetek, dywidend (udziałów w zyskach) lub innych pożytków, w tym również z transakcji handlowej, a w szczególności aktywa finansowe oraz te nieruchomości i wartości niematerialne i prawne, które nie są użytkowane przez jednostkę, lecz są posiadane przez nią w celu osiągnięcia tych korzyści. W przypadku zakładów ubezpieczeń i zakładów reasekuracji przez inwestycje rozumie się lokaty - art. 3 ust. 1 pkt 17.

${ }^{2}$ Stownik wyrazów obcych, red. J. Tokarski, Warszawa 1980, s. 315.

${ }^{3}$ D. Sypniewski, Nadzór nad procesem budowlanym, Warszawa 2011, s. 55-56.

${ }^{4}$ I. Weiss, R. Jurga, Inwestycje budowlane, Warszawa 2005, s. 3. 
Podstawowymi aktami normatywnymi regulującymi proces budowlany są: ustawa z dnia 27 marca 2003 r. o planowaniu i zagospodarowaniu przestrzennym $^{5}$ oraz ustawa z dnia 7 lipca 1994 r. - Prawo budowlane ${ }^{6}$. Dopełnienie stanowią przepisy wielu aktów normatywnych, wśród których wymienić należy: ustawę z dnia 9 czerwca 2011 r. - Prawo geologiczne i górnicze ${ }^{7}$, ustawę z dnia 27 kwietnia 2001 r. - Prawo ochrony środowiska ${ }^{8}$, ustawę z dnia 16 kwietnia 2004 r. o ochronie przyrody ${ }^{9}$, ustawę z dnia 18 lipca 2001 r. - Prawo wodne ${ }^{10}$, ustawę z dnia 3 lutego 1995 r. o ochronie gruntów rolnych i leśnych ${ }^{11}$, ustawę z dnia 23 lipca 2003 r. o ochronie zabytków i opiece nad zabytkami ${ }^{12}$, ustawę z dnia 21 marca 1985 r. o drogach publicznych ${ }^{13}$.

Zaznaczyć należy, że w procesie budowlanym mają zastosowanie również przepisy kodeksu postępowania administracyjnego ${ }^{14}$, ponieważ zasadniczą część postępowań podejmowanych w tym procesie stanowią postępowania administracyjne szczególne. Charakteryzują się one wprawdzie odrębnościami proceduralnymi względem przepisów kodeksu postępowania administracyjnego, ale stosowanie przepisów procesowych w przedmiotowych postępowaniach następuje zgodnie z zasadą lex specialis derogat legi generali. Oznacza to, że w postępowaniach prowadzonych w toku procesu budowlanego w pierwszej kolejności stosuje się zawarte w regulującej daną problematykę ustawie zaliczanej do źródeł prawa budowlanego - przepisy procesowe szczególne, a następnie - jeśli w ustawie tej nie zawarto odrębnego uregulowania - ogólne regulacje proceduralne zawarte w kodeksie postępowania administracyjnego ${ }^{15}$.

${ }^{5}$ T.j. Dz.U. z 2012 r., poz. 647 z późn. zm.

${ }^{6}$ T.j. Dz.U. z 2013 r., poz. 1409 z późn. zm.

7 T.j. Dz.U. z 2014 r., poz. 613.

${ }^{8}$ T.j. Dz.U. z 2013 r., poz. 1232 z późn. zm.

${ }^{9}$ T.j. z 2013 r., poz. 627 z późn. zm.

${ }^{10}$ T.j. z 2012 r., poz. 145 z późn. zm.

${ }^{11}$ T.j. z 2013 r., poz. 1205 z późn. zm.

12 Dz.U. z 2003 r., nr 162, poz. 1568 z późn. zm.

13 T.j. z 2013 r., poz. 260 z późn. zm.

${ }^{14}$ Ustawa z 14.06.1960 r. Kodeks postępowania administracyjnego (t.j.Dz.U z 2013 r., poz. 267 z późn. zm.).

${ }^{15} \mathrm{~K}$. Małysa-Sulińska, Administracyjnoprawne aspekty inwestycji budowlanych, Warszawa 2012, s. 24 i cytowana tam literatura. 
Regulacje procesu budowlanego mają charakter reglamentacyjny. Zawierają zakazy i nakazy typu policyjnego podyktowane interesem ogólnym, a zwłaszcza potrzebą wprowadzenia ładu, porządku i bezpieczeństwa, a niekiedy ochrony innych dóbr. Prawo budowlane normuje proces budowlany z punktu widzenia potrzeb policji budowlanej, dyktowanych przez dobro interesu publicznego i podkreśla, jako dominujący w prawnej regulacji poszczególnych stadiów procesu, aspekt związany z zapewnieniem bezpieczeństwa osób i mienia ${ }^{16}$.

Zakres i formy ingerencji organów architektoniczno-budowlanych i organów nadzoru budowlanego w sferę wolności budowlanej muszą być określone ustawowo i nie można ich domniemywać ani dokonywać wykładni rozszerzającej $^{17}$. Zasadą jest, że podejmowanie aktywności budowlanej wymaga uzyskania zgody właściwego organu administracji publicznej. Zgoda może przybrać postać decyzji administracyjnej lub może być wyrażona także w sposób dorozumiany poprzez milczenie właściwego organu w odniesieniu do dokonanego zgłoszenia podjęcia określonej czynności. Z regulacji prawa budowlanego wynika, że ustawodawca założył konieczność wymuszania pewnych zachowań w procesie budowlanym. W związku z powyższym organy administracji publicznej zostały wyposażone w uprawnienia władcze.

\section{Przeznaczenie terenu}

Zagospodarowanie przestrzenne to racjonalne korzystanie z otaczającej nas przestrzeni i jej elementów składowych. Pojęcie zagospodarowania obejmuje $\mathrm{w}$ języku polskim ${ }^{18}$ racjonalne wykorzystanie przestrzeni lub określonych zasobów. Wskazanie na aspekt planowania oznacza, że korzystanie z przestrzeni i jej zasobów odbywa się według reguł określonych w tych planach. W przypadku planowania opartego na normach, ważne jest sprecyzowanie uprawnień i obowiązków zawartych w planach i skierowanych do określonych podmiotów (organów) odpowiedzialnych za racjonalne korzystanie z przestrzeni (również reglamentujących prawo do tego korzystania) czy też do podmiotów korzystających z tej przestrzeni i jej elementów składowych. Zagospodarowanie przestrzenne okre-

${ }^{16}$ M. Stahl, w: Materialne prawo administracyjne. Pojęcia, instytucje, zasady, red. M. Stahl, wyd. 2, Warszawa 2005, s. 345.

${ }^{17}$ Ibidem, s. 347.

${ }^{18}$ Uniwersalny słownik języka polskiego, red. S. Dubisz, Warszawa 2003, s. 458. 
ślające prawo do korzystania $\mathrm{z}$ terenu jest ściśle połączone z problematyką prawa budowlanego, tworząc podstawy procesu inwestycyjnego ${ }^{19}$.

Jednym z zadań odgrywających coraz większą rolę w systemie zadań publicznych, jest planowanie przestrzenne. Ustawa z dnia 27 marca 2003 r. o planowaniu i zagospodarowaniu przestrzennym wyposażyła gminę w kompetencje w zakresie planowania i zagospodarowania przestrzennego, określane zbiorczo jako władztwo planistyczne ${ }^{20}$. Rada gminy dysponuje instrumentami pozwalającymi na ustalenie przeznaczenia i zasad zagospodarowania terenów położonych na obszarze gminy ${ }^{21}$. To ona stanowi o przeznaczeniu i zasadach zagospodarowania terenu. Tylko jej rozstrzygnięcia planistyczne mają moc obowiązującą i wiążą właścicieli gruntów. Takich uprawnień nie ma żadna inna jednostka samorządu terytorialnego, a tym bardziej administracja rządowa. W tej sytuacji to gmina staje się podstawą systemu planowania przestrzennego ${ }^{22}$.

Przeznaczenie terenu, rozmieszczenie inwestycji celu publicznego oraz określenie sposobów zagospodarowania i warunków zabudowy terenu następuje w miejscowym planie zagospodarowania przestrzennego. Jego konstrukcja i treść zależne są od okoliczności, takich jak rodzaj i wielkość obszaru, dla którego ma być sporządzany, a także od czasu, w jakim będą obowiązywały jego poszczególne ustalenia. Obszar planu nie może wykraczać poza granice administracyjne gminy, ale może być od nich mniejszy. Wielkość obszaru może wynikać z potrzeb kształtowania przestrzeni publicznych, do których zalicza się obszar o szczególnym znaczeniu dla zaspokojenia potrzeb mieszkańców ${ }^{23}$.

W tym miejscu należy jeszcze wspomnieć o studium uwarunkowań i kierunków zagospodarowania przestrzennego. Jako akt kierownictwa wewnętrznego jest poddawany procedurze zbliżonej do tej, która obowiązuje przy sporządzaniu planu miejscowego ${ }^{24}$. W treści studium uwzględnia się miedzy innymi uwarunkowania wynikające z dotychczasowego przeznaczenia, uzbrojenia i zagospodarowania terenu, stanu środowiska, rolniczej i leśnej przestrzeni produkcyjnej,

${ }^{19}$ H. Nowicki, w: Aspekty prawne planowania i zagospodarowania przestrzennego, red. W. Szwajdler, Warszawa 2013, s. 13.

${ }^{20}$ Wyrok NSA z 12.05.2011 r., sygn. akt II OSK 355/11, CBOSA.

${ }^{21}$ Wyrok NSA z 19.01.2012 r., sygn. akt II OSK 2373/11, CBOSA.

22 Z. Niewiadomski, Planowanie przestrzenne. Zarys systemu, wyd. 2, Warszawa 2003, s. 85.

${ }^{23}$ P. Kwaśniak, Plan miejscowy w systemie zagospodarowania przestrzennego, wyd. 3, Warszawa 2011, s. 68 .

${ }^{24}$ Z. Niewiadomski, Nowe prawo o planowaniu i zagospodarowaniu przestrzennym, Warszawa 2003, s. 20-21. 
jakości i wielkości zasobów wodnych, wymogów ochrony środowiska, krajobrazu, stanu prawnego gruntów, występowania terenów i obiektów chronionych, zasobów wód podziemnych i udokumentowanych złóż kopalin, stanu systemów infrastruktury technicznej i komunikacji, a także zadań służących realizacji ponadlokalnych celów publicznych.

Obecnie ranga studium jest wysoka, ponieważ zawarte w nim uregulowania są dla gminy wiążące przy tworzeniu i uchwalaniu planów miejscowych. Istotną rolę i znaczenie podkreśla obligatoryjność jego sporządzenia i uchwalenia. Brak tego aktu uniemożliwia bowiem uchwalenie planów miejscowych. Poza tym studium jest opracowaniem, które ma promować gminę, ukazując jej gospodarcze i przestrzenne perspektywy rozwoju. Powinno być zatem swego rodzaju prezentacją możliwości gminy, mającą na celu przyciągnięcie inwestorów. Poza pełnieniem funkcji aktu polityki przestrzennej oraz strategii rozwoju przestrzennego gminy jego zadaniem jest wyznaczenie obszarów zmian w planowaniu i zagospodarowaniu przestrzennym na jej terenie. Jest dokumentem przewodnim w stosunku do planu miejscowego i ma inspirować zamierzenia planistyczne organów gminy ${ }^{25}$.

W przypadku braku miejscowego planu, określenie sposobów zagospodarowania i warunków zabudowy terenu następuje w formie decyzji o warunkach zabudowy i zagospodarowania terenu, jednakże lokalizację inwestycji celu publicznego ustala się w formie decyzji o ustaleniu lokalizacji inwestycji celu publicznego, a sposób zagospodarowania terenu i warunki zabudowy dla innych inwestycji - w formie decyzji o warunkach zabudowy.

Sporządzanie miejscowych planów zagospodarowania przestrzennego co do zasady - nie jest obligatoryjne. W związku z powyższym organy gminy samodzielnie decydują o podjęciu prac nad planami miejscowymi, przesądzając o ich liczbie i zakresie terenowym. Jednak od zasady fakultatywnego sporządzania miejscowych planów zagospodarowania przestrzennego ustawodawca wprowadza wyjątki, wskazując przypadki, gdy sporządzenie planu miejscowego jest obligatoryjne ${ }^{26}$.

Miejscowy plan zagospodarowania przestrzennego zajmuje wśród aktów kształtujących ład przestrzenny miejsce szczególne, gdyż jest on aktem prawa

${ }^{25}$ P. Kwaśniak, Plan ..., s. 68.

${ }^{26}$ Art. 14 ust. 7 ustawy z 27.03.2003 r. o planowaniu i zagospodarowaniu przestrzennym stanowi, że plan miejscowy sporządza się obowiązkowo, jeżeli wymagają tego przepisy odrębne. Przykładowo: art. 55 ust. 9 ustawy z dnia 3.07.2002 r. Prawo lotnicze (t.j. Dz.U. z 2013 r., poz. 1393 z późn. zm.). 
miejscowego. Oznacza to, że jego ustalenia przybierają postać przepisów powszechnie obowiązujących na obszarze danej gminy. W związku z tym, ustalenia planu miejscowego - inaczej niż ustalenia pozostałych aktów kształtujących ład przestrzenny ${ }^{27}$ - wiążą nie tylko organy administracji publicznej, lecz także inne podmioty, w tym właścicieli nieruchomości objętych ustaleniami tego planu. Mogą stanowić podstawę indywidualnych i konkretnych rozstrzygnięć wydawanych w sprawach administracyjnych ${ }^{28}$.

Ustalenia miejscowego planu zagospodarowania przestrzennego mogą stanowić podstawę prawną do wydawania decyzji administracyjnych, w szczególności w sprawach o pozwolenie na budowę. Ustalenia planu miejscowego - choć wskazują przeznaczenie ściśle oznaczonego terenu - nie rozstrzygają o konkretnym jego przeznaczeniu i sposobie zagospodarowania. Rozstrzygnięcie w tym zakresie może bowiem zapaść jedynie w drodze indywidualnego aktu administracyjnego, jakim jest pozwolenie na budowę. Każdy ma prawo do zagospodarowania terenu, do którego posiada tytuł prawny, zgodnie z warunkami ustalonymi w miejscowym planie zagospodarowania przestrzennego, z zastrzeżeniem, że nie narusza to chronionego prawem interesu publicznego oraz chronionego interesu osób trzecich. Rozstrzygnięcie w indywidualnej sprawie administracyjnej, $\mathrm{w}$ tym także w przedmiocie udzielenia pozwolenia na budowę, podjęte w oparciu o ustalenia planu miejscowego, musi jednak wyraźnie wynikać zarówno z części tekstowej, jak i części graficznej tego planu. Mając na uwadze powyższe, wskazać należy, iż jakakolwiek rozszerzająca wykładnia ustaleń planu miejscowego na niekorzyść właścicieli nieruchomości jest sprzeczna z konstytucyjną zasadą ochrony prawa własności i stanowi rażące naruszenie ustaleń tego planu ${ }^{29}$.

Zatem teren podlegający ustaleniom obowiązującego planu miejscowego może być zagospodarowany tylko w taki sposób, na jaki zezwalają ustalenia tego planu. Oznacza to, że od chwili wejścia w życie miejscowego planu zagospodarowania przestrzennego postępowanie w przedmiocie ustalenia warunków zabudowy i zagospodarowania terenu nie może się toczyć i jako bezprzedmiotowe - podlega umorzeniu na podstawie art. $105 \S 1$ Kodeksu postępowania administracyjnego ${ }^{30}$.

${ }^{27}$ K. Małysa-Sulińska, w: Przestrzeń i nieruchomości jako przedmiot prawa administracyjnego. Publiczne prawo rzeczowe, red. I. Niżnik-Dobosz, Warszawa 2012, s. 60.

${ }^{28}$ Wyrok SN z 22.02.2002 r., sygn. akt III RN 203/2000, OSNP 2001, nr 20, poz. 606.

${ }^{29}$ K. Małysa-Sulińska, Administracyjnoprawne..., s. 42-43.

${ }^{30}$ Wyrok WSA w Krakowie z 21.12.2010 r., sygm. akt II SA/Kr 1171/10, Lex nr 753446. 
Organy wykonawcze jednostek samorządu terytorialnego wszystkich szczebli obowiązane są do przedstawiania wojewodzie każdej uchwały w ciągu 7 dni od jej przyjęcia. Wynika z tego obowiązek (wójta, burmistrza, prezydenta miasta) przedłożenia wojewodzie uchwały w sprawie uchwalenia planu miejscowego oraz innych uchwał planistycznych ją poprzedzających.

Działanie ostrzegawcze organu nadzorującego, w materii planowania i zagospodarowania przestrzennego, polegać może na wezwaniu przez wojewodę rady gminy do uchwalenia studium lub jego zmiany w wyznaczonym terminie lub na wezwaniu do uchylenia kwestionowanej uchwały planistycznej. Działaniem prewencyjnym może być podjęcie czynności zmierzających do uzgodnienia terminu realizacji określonych inwestycji oraz warunków wprowadzenia ich do aktu planistycznego. Działanie prewencyjne może doprowadzić do uregulowania przez organ nadzorczy określonej kwestii za gminę w przypadku zaniechania przez gminę wymaganej aktywności ${ }^{31}$. Środkiem represyjnym organu nadzoru będzie orzeczenie o nieważności uchwały organu samorządu.

Gdy na obszarze planowanej inwestycji celu publicznego nie obowiązuje miejscowy plan zagospodarowania przestrzennego, wymagane jest uzyskanie decyzji o ustaleniu lokalizacji inwestycji celu publicznego. Zgodnie z art. 2 pkt 5 ustawy o planowaniu i zagospodarowaniu przestrzennym, przez inwestycję celu publicznego należy rozumieć działania o znaczeniu lokalnym (gminnym) i ponadlokalnym (powiatowym, wojewódzkim i krajowym), a także krajowym (obejmującym również inwestycje międzynarodowe i ponadregionalne), bez względu na status podmiotu podejmującego te działania oraz źródła ich finansowania, stanowiące realizację celów, o których mowa w art. 6 ustawy z dnia 21 sierpnia 1997 r. o gospodarce nieruchomościami ${ }^{32}$. Można tu przykładowo wymienić takie inwestycje, jak: remonty i budowa dróg publicznych, utrzymywanie i budowa publicznych urządzeń przeznaczonych do zaopatrywania ludności w wodę, przesyłania i oczyszczania ścieków, gromadzenia i utylizacji odpadów, ponadto utrzymywanie i budowa budynków i pomieszczeń dla organów administracji, obiektów ochrony zdrowia, sądów, prokuratur, szkół publicznych. Jest to przykładowe wyliczenie, mające uwidocznić, jakiego rodzaju zagadnień dotyczy decyzja o ustaleniu lokalizacji inwestycji celu publicznego.

${ }^{31}$ P. Kwaśniak, Plan ..., s. 288-289.

32 Ustawa z 21.08.1997 r. o gospodarce nieruchomościami (t.j. Dz.U. z 2014 r., poz. 518 z późn. zm.). 
Mając na uwadze powyższe, wskazać należy, że art. 6 ustawy o gospodarce nieruchomościami stanowi katalog zamknięty celów publicznych, który nie może zostać poszerzony w drodze wykładni ${ }^{33}$.

Przed wydaniem decyzji o ustaleniu lokalizacji inwestycji celu publicznego przeprowadzane jest postępowanie wyjaśniające polegające na analizie zasad i warunków zagospodarowania terenu oraz jego zabudowy, wynikających z odrębnych przepisów oraz stanu prawnego i faktycznego obszaru, na którym jest przewidziana inwestycja.

O obowiązku wnikliwej analizy przez właściwe organy administracji samorządowej i rządowej decyzji o ustaleniu lokalizacji inwestycji celu publicznego w ramach systemu planowania i zagospodarowania przestrzennego świadczy to, że marszałek województwa prowadzi rejestr tych decyzji o znaczeniu krajowym i wojewódzkim. Wójt, burmistrz, prezydent miasta prowadzą rejestr wydanych decyzji o znaczeniu powiatowym i gminnym, a wojewoda prowadzi rejestr wydanych decyzji na terenach zamkniętych. Wójt, burmistrz, prezydent miasta przekazują marszałkowi województwa kopie decyzji o znaczeniu krajowym, wojewódzkim, powiatowym i gminnym, w terminie 7 dni od ich wydania ${ }^{34}$.

Zamieszczenie w rejestrach informacji dotyczących decyzji o ustaleniu lokalizacji inwestycji celu publicznego wskazuje na cechę koordynującą marszałka województwa w zakresie lokalizacji wszelkich inwestycji celu publicznego ${ }^{35}$.

Ustawa o planowaniu i zagospodarowaniu przestrzennym reguluje zarówno treść, jaką decyzja lokalizacyjna powinna zawierać, jak i procedurę jej wydawania. Wpływa to bezpośrednio na organy administracyjne wydające te decyzje w ten sposób, że minimalizuje możliwość ich interpretacji. Najbardziej istotnym elementem ochrony interesu publicznego jest w tym przypadku utrzymanie ładu przestrzennego. Temu właśnie służy uregulowanie gospodarowania przestrzenią w sytuacji braku planu miejscowego ${ }^{36}$.

Jeżeli na obszarze planowanego zamierzenia inwestycyjnego, które nie jest kwalifikowane jako inwestycja celu publicznego, nie obowiązuje miejscowy plan zagospodarowania przestrzennego, warunki zabudowy i zagospodarowa-

${ }^{33}$ Wyrok NSA-OZ w Krakowie z 10.10.2000 r., sygn. akt II SA/Kr 1010/00, ONSA 2001, nr 4, s. 186.

${ }^{34}$ Regulacje wprowadzone Ustawą z dnia 7 maja 2010 r. o wspieraniu rozwoju usług i sieci telekomunikacyjnych (Dz.U. z 2010 r., nr 106, poz. 675 z późn. zm.) z dniem 17 lipca 2010 r.

35 P. Kwaśniak, Plan ..., s. 84.

${ }^{36} \mathrm{~K}$. Jaroszyński, w: Ustawa o planowaniu i zagospodarowaniu przestrzennym, przepisy omówienia - komentarze, red. G. Buczek, M. Tetera-Jankowska, Warszawa 2003, s. 69. 
nia terenu określane są w formie decyzji o warunkach zabudowy. Podobnie jak decyzja o ustaleniu lokalizacji inwestycji celu publicznego, decyzja o warunkach zabudowy jest rozstrzygnięciem, w którym potwierdza się możliwość realizowania na konkretnym obszarze, wskazanej we wniosku inicjującym postępowanie, projektowanej inwestycji.

Uzyskanie decyzji o warunkach zabudowy jest wymagane, gdy planowana jest zmiana zagospodarowania terenu polegająca na budowie obiektu budowlanego lub wykonaniu innych robót budowlanych, a także zmianie sposobu użytkowania obiektu lub jego części. Wymóg uzyskania przedmiotowej decyzji dotyczy również przypadków, gdy planowana jest zmiana zagospodarowania terenu niewymagająca pozwolenia na budowę z wyjątkiem tymczasowej, jednorazowej zmiany zagospodarowania terenu, trwającej do roku.

Regulacja art. 61 ust. 1 ustawy o planowaniu i zagospodarowaniu przestrzennym zobowiązuje do zapewnienia zgodności ustalającej warunki zabudowy nie tylko z przepisami szczególnymi, ale jednocześnie łącznego spełnienia warunków: co najmniej jedna działka sąsiednia, dostępna z tej samej drogi publicznej, jest zabudowana w sposób pozwalający na określenie wymagań dotyczących nowej zabudowy w zakresie kontynuacji funkcji, parametrów, cech i wskaźników kształtowania zabudowy oraz zagospodarowania terenu, w tym gabarytów i formy architektonicznej obiektów budowlanych, linii zabudowy oraz intensywności wykorzystania terenu; teren ma dostęp do drogi publicznej; istniejące lub projektowane i umownie zabezpieczone uzbrojenie terenu jest wystarczające dla zamierzenia budowlanego; teren nie wymaga uzyskania zgody na zmianę przeznaczenia gruntów rolnych i leśnych na cele nierolnicze i nieleśne albo jest objęty zgodą uzyskaną przy sporządzaniu miejscowych planów, które utraciły moc; decyzja jest zgodna z przepisami odrębnymi.

Ustawodawca, respektując na obszarach pozbawionych planu generalną zasadę wolności zabudowy w granicach określonych przepisami szczególnymi, wprowadził zasadę „dobrego sąsiedztwa”. Przyjęta z ustawodawstwa niemieckiego zasada zobowiązuje organ do ustalenia warunków zabudowy dopiero wówczas, gdy - niezależnie od spełnienia innych prawem wymaganych warunków - zamierzenie inwestycyjne jest lokalizowane w sąsiedztwie co najmniej jednej działki zabudowanej i to na zasadzie kontynuacji funkcji terenu. Zasada dobrego sąsiedztwa ma przeciwdziałać zabudowie rozproszonej tak, aby nie było konieczności rozbudowy drogiej infrastruktury technicznej ${ }^{37}$. Jej celem jest też

${ }^{37}$ Z. Niewiadomski, Planowanie..., s. 128-129. 
doprowadzenie do wprowadzenia i utrzymania ładu przestrzennego na określonym terenie. Ma zatem umożliwić takie ukształtowanie przestrzeni, które tworzy harmonijną całość oraz uwzględnia, w uporządkowanych relacjach, wszelkie uwarunkowania i wymagania funkcjonalne, społeczno-gospodarcze, środowiskowe, kulturowe oraz kompozycyjno-estetyczne ${ }^{38}$. Warto zaznaczyć, że istnieją wyjątki od powyższej zasady. Odnoszą się one do inwestycji produkcyjnych lokalizowanych na ten cel w planach miejscowych przed 1995 r., które utraciły moc w grudniu 2002 r., oraz do linii kolejowych, urząazeń infrastruktury technicznej i obiektów liniowych. Zasada ta nie obowiązuje również przy zabudowie zagrodowej, gdy powierzchnia gospodarstwa rolnego z tą zabudową związanego jest większa od uśrednionej powierzchni takiego gospodarstwa w określonej gminie. Jeżeli gospodarstwo zajmuje znaczną powierzchnię, to do przeprowadzenia inwestycji na jego terenie nie jest potrzebna sąsiednia działka, zabudowana zgodnie z zasadą ,dobrego sąsiedztwa" 39 .

Sposób ustalania wymagań dotyczących nowej zabudowy i zagospodarowania terenu w przypadku braku planu miejscowego określa rozporządzenie wykonawcze Ministra Infrastruktury ${ }^{40}$, które precyzuje wymagania dotyczące ustalenia: linii zabudowy; wielkości powierzchni zabudowy w stosunku do powierzchni działki albo terenu; szerokości elewacji frontowej; wysokości górnej krawędzi elewacji frontowej, jej gzymsu lub attyki; geometrii dachu (kąta nachylenia, wysokości kalenicy i układu połaci dachowych).

Decyzja o warunkach zabudowy powinna określać rodzaj inwestycji, warunki szczegółowe zasady zagospodarowania terenu oraz jego zabudowy wynikające z przepisów szczególnych, w tym warunki obsługi w zakresie infrastruktury technicznej i wymagania dotyczące ochrony interesów osób trzecich, linie rozgraniczające teren inwestycji, wyznaczone na mapie w stosownej skali. Decyzję o warunkach zabudowy wydaje wójt, burmistrz albo prezydent miasta, po uzyskaniu uzgodnień lub rozstrzygnięć wymaganych ustawą i przepisami szczególnymi. W odniesieniu do terenów zamkniętych decyzję wydaje woje-

${ }^{38}$ Wyrok NSA w Warszawie z 17.04.2007 r., sygn. akt II OSK 646/06, LexPolonica nr 2118199; Wyrok NSA w Warszawie z 26.01.2007 r., sygn. akt II OSK 239/06, LexPolonica nr 2118120.

${ }^{39}$ Ustawa o planowaniu i zagospodarowaniu przestrzennym. Komentarz, red. Z. Niewiadomski, Warszawa 2004, s. 504-505.

${ }^{40}$ Rozporządzenie Ministra Infrastruktury z 26.08.2003 r. w sprawie sposobu ustalania wymagań dotyczących nowej zabudowy i zagospodarowania terenu w przypadku braku miejscowego planu zagospodarowania przestrzennego (Dz.U. z 2003 r., nr 164, poz. 1588). 
woda, a w stosunku do morskich wód wewnętrznych i morza terytorialnego dyrektor właściwego miejscowo urzędu morskiego.

W celu gromadzenia informacji o zagospodarowaniu terenu ustawodawca zobowiązał wójta, burmistrza, prezydenta miasta do prowadzenia rejestru wydanych decyzji o warunkach zabudowy, a inne organy do przesyłania do gmin odpisów decyzji w indywidualnych sprawach z zakresu administracji publicznej, dotyczących zagospodarowania terenów gminy pod rygorem odpowiedzialności za szkodę tym wyrządzoną.

\section{Zgoda na podjęcie robót budowlanych}

Aby rozpocząć roboty budowlane, należy najpierw podjąć stosowne działania. Zasadą jest, że roboty można rozpocząć na podstawie ostatecznej decyzji o pozwoleniu na budowę. W związku z tym legalne prowadzenie robót budowlanych wymaga uprzedniego przeprowadzenia postępowania administracyjnego i wydania decyzji w sprawie zatwierdzenia projektu budowlanego i udzielenia pozwolenia na budowę. Jednakże ustawodawca wprowadził odstępstwa od tej zasady, wskazując nieskomplikowane pod względem technicznym roboty, których realizacja nie wymaga uzyskania przedmiotowej decyzji. Należy podkreślić, że roboty wymienione w art. 29 ust. 1 i 2 ustawy Prawo budowlane tworzą kata$\log$ zamknięty, a w związku z tym niedopuszczalna jest wykładnia rozszerzająca tego przepisu.

Pozwolenie na budowę nie stanowi jedynego przejawu reglamentacji możliwości przystąpienia do wykonywania robót budowlanych. Roboty budowlane zwolnione od obowiązku uzyskania pozwolenia na budowę zostały bowiem objęte obowiązkiem ich zgłoszenia. Oznacza to, że wykonywanie tych robót powinno zostać poprzedzone skierowaniem stosownego zawiadomienia (zgłoszenia) do właściwego organu administracji publicznej. Rozpoczęcie robót budowlanych wskazanych w art. 30 ust. 1 prawa budowlanego zostało poddane reglamentacji administracyjnej w uproszczonej formie - niewymagającej wydania decyzji administracyjnej.

Wąska kategoria robót budowlanych nie podlega obowiązkowi uzyskania pozwolenia na budowę oraz dokonania zgłoszenia ich wykonywania. Wyłączona spod reglamentacji administracyjnej została możliwość przystąpienia do realizacji nieskomplikowanych zamierzeń budowlanych, które stwarzają niewielkie zagrożenie dla bezpieczeństwa ludzi, mienia oraz środowiska naturalnego. Będzie 
to przykładowo budowa: obiektów małej architektury ${ }^{41}$; ogrodzeńn ${ }^{42}$; obiektów przeznaczonych do czasowego użytkowania w trakcie realizacji robót budowlanych, położonych na terenie budowy, oraz ustawianie barakowozów używanych przy wykonywaniu robót budowlanych, badaniach geologicznych i pomiarach geodezyjnych; tymczasowych obiektów budowlanych stanowiących wyłącznie eksponaty wystawowe, niepełniących jakichkolwiek funkcji użytkowych, usytuowanych na terenach przeznaczonych na ten cel. Pozwolenia na budowę oraz zgłoszenia nie wymaga wykonywanie robót budowlanych polegających na instalowaniu: krat na obiektach budowlanych ${ }^{43}$; urządzeń, w tym antenowych konstrukcji wsporczych i instalacji radiokomunikacyjnych na obiektach budowlanych ${ }^{44}$; (montażu) pomp ciepła, urządzeń fotowoltaicznych o zainstalowanej mocy elektrycznej do $40 \mathrm{~kW}$ oraz wolno stojących kolektorów słonecznych.

Podkreślenia wymaga jednak, że przy wykonywaniu takich robót budowlanych należy przestrzegać przepisów prawa budowlanego, a w szczególności przepisów techniczno-budowlanych.

Przystąpienie do realizacji robót budowlanych bez wymaganego pozwolenia na budowę lub zgłoszenia zamiaru ich wykonywania stanowi jeden z przejawów samowoli budowlanej. W takiej sytuacji właściwy organ nadzoru budowlanego może zastosować określone uprawnienia policyjne.

Zgłoszenie przez inwestora zamiaru wykonywania robót budowlanych jest równoznaczne z wyrażeniem chęci przystąpienia do realizacji planowanego przedsięwzięcia. Postępowanie „zgłoszeniowe” jest w pewnym sensie „uproszczone", dlatego że - co do zasady - nie wymaga wydania decyzji administracyjnej. Pozytywne rozstrzygnięcie dla inwestora stanowi bowiem ,milcząca akceptacja” właściwego organu. Ponadto do postępowania w sprawie zgłoszenia zamiaru wykonywania robót nie mają w pełni zastosowania przepisy kodeksu postępowania administracyjnego ${ }^{45}$.

${ }^{41}$ Budowa obiektów małej architektury w miejscach publicznych wymaga dokonania zgłoszenia - art. 30 ust. 1 pkt 4 prawa budowlanego.

42 Budowa ogrodzeń od strony dróg, ulic, placów, torów kolejowych i innych miejsc publicznych oraz ogrodzeń o wysokości powyżej 2,20 m wymaga dokonania zgłoszenia - art. 30 ust. 1 pkt 3 prawa budowlanego.

${ }^{43}$ Instalowanie krat na budynkach mieszkalnych wielorodzinnych, użyteczności publicznej i zamieszkania zbiorowego oraz obiektach wpisanych do rejestru zabytków wymaga dokonania zgłoszenia - art. 30 ust. 1 pkt 3a prawa budowlanego.

${ }^{44}$ Instalowanie urządzeń o wysokości powyżej $3 \mathrm{~m}$ na obiektach budowlanych wymaga dokonania zgłoszenia - art. 30 ust. 1 pkt $3 \mathrm{~b}$ prawa budowlanego.

${ }^{45}$ Wyrok NSA z 17.11.2005 r., sygn. akt II OSK 197/05, Lex nr 196647. 
Po dokonaniu zgłoszenia następuje analiza materiałów, a także ocena, czy w konkretnym przypadku dopuszczalne jest podjęcie realizacji planowanego przedsięwzięcia. Należy zaznaczyć, że czynności prowadzone przez organ właściwy w przedmiocie przyjęcia zgłoszenia zamiaru wykonywania robót budowlanych nie następują przy udziale stron postępowania, o których mowa w art. 28 Kodeksu postępowania administracyjnego. Podmioty zainteresowane mogą kwestionować przyzwolenie organu na rozpoczęcie robót budowlanych objętych zgłoszeniem zamiaru ich wykonywania wyłącznie w trybie przepisów działu VIII Kodeksu postępowania administracyjnego ${ }^{46}$.

Zgodnie z art. 30 ust. 5 zdaniem drugim prawa budowlanego, inwestor może przystąpić do wykonywania robót budowlanych enumeratywnie wskazanych $\mathrm{w}$ art. 30 ust. 1 prawa budowlanego, jeżeli w terminie 30 dni od dnia doręczenia zgłoszenia właściwy organ nie wniesie, w drodze decyzji, sprzeciwu i nie później niż po upływie 2 lat od określonego w zgłoszeniu terminu ich rozpoczęcia. Podstawę do wyrażenia sprzeciwu przez organ administracji architektoniczno-budowlanej stanowią następujące sytuacje: inwestor nie uzupełnił w terminie braków zgłoszenia, mimo uprzedniego wezwania przez organ art. 30 ust. 2 zdanie trzecie prawa budowlanego; zgłoszenie dotyczy budowy lub wykonywania robót budowlanych objętych obowiązkiem uzyskania pozwolenia na budowę - art. 30 ust. 6 pkt 1 prawa budowlanego; budowa lub wykonywanie robót budowlanych objętych zgłoszeniem narusza ustalenia miejscowego planu zagospodarowania przestrzennego lub inne przepisy - art. 30 ust. 6 pkt 2 prawa budowlanego; zgłoszenie dotyczy budowy tymczasowego obiektu budowlanego, niepołączonego trwale $\mathrm{z}$ gruntem i przewidzianego do rozbiórki albo przeniesienia w inne miejsce w terminie określonym w zgłoszeniu, w miejscu, w którym taki obiekt istnieje - art. 30 ust. 6 pkt 3 prawa budowlanego.

Inne przesłanki wniesienia sprzeciwu wobec zamierzenia inwestycyjno-budowlanego wynikają z art. 30 ust. 7 prawa budowlanego. Zgodnie z tym przepisem organ może nałożyć, w drodze decyzji zawierającej sprzeciw, obowiązek uzyskania pozwolenia na wykonanie określonego obiektu lub robót budowlanych objętych obowiązkiem zgłoszenia, jeżeli ich realizacja może naruszać ustalenia

${ }^{46}$ Skargi i wnioski są wnoszone i rozpatrywane na podstawie działu VIII kodeksu postępowania administracyjnego. Stanowią realizację konstytucyjnego prawa wynikającego z art. 63 Konstytucji RP. W myśl tego artykułu: „Każdy ma prawo składać petycje, wnioski i skargi w interesie publicznym, własnym lub innej osoby za jej zgodą do organów władzy publicznej oraz do organizacji i instytucji społecznych w związku z wykonywanymi przez nie zadaniami zleconymi z zakresu administracji publicznej". 
miejscowego planu zagospodarowania przestrzennego lub spowodować: zagrożenie bezpieczeństwa ludzi lub mienia; pogorszenie stanu środowiska lub stanu zachowania zabytków; pogorszenie warunków zdrowotno-sanitarnych; wprowadzenie, utrwalenie bądź zwiększenie ograniczeń lub uciążliwości dla terenów sąsiednich.

Zgodnie $\mathrm{z}$ art. 30 ust. 5 zdaniem drugim prawa budowlanego formę zakończenia procedury zgłoszenia robót budowlanych stanowi także ,niewniesienie sprzeciwu" przez właściwy organ w terminie 30 dni od dnia doręczenia zgłoszenia (lub od dnia usunięcia braków zgłoszenia, jeżeli do tego był wzywany inwestor - art. 30 ust. 2 zdanie trzecie) ${ }^{47}$. Przez „niewniesienie sprzeciwu” w terminie 30 dni od doręczenia zgłoszenia robót budowlanych (art. 30 ust. 5 zdanie drugie) należy rozumieć sytuację, gdy w tym okresie nie doręczono (ogłoszono) inwestorowi decyzji administracyjnej odmawiającej zezwolenia na realizację zamierzenia inwestycyjnego ${ }^{48}$.

Należy jeszcze wspomnieć o trzeciej formie merytorycznego zakończenia postępowania dotyczącego zgłoszenia robót budowlanych, a mianowicie o zawiadomieniu inwestora o braku zamiaru wniesienia sprzeciwu. Z. Leoński stoi na stanowisku, że nie ma przeszkód, by organ administracji architektoniczno-budowlanej wyraził zgodę na rozpoczęcie robót budowlanych przed upływem terminu 30 dni od doręczenia zgłoszenia, jeśli nie ma zamiaru wnieść sprzeciwu ${ }^{49}$. R. Dziwiński i P. Ziemski dodają, że legalne przystąpienie do realizacji inwestycji będzie możliwe natychmiast po doręczeniu takiej „pisemnej informacji” ${ }^{50}$. T.B. Babiel upatruje w takim zachowaniu się organu przejawu realizacji zasady pogłębiania zaufania obywateli do organów Państwa (art. 8 Kodeksu postępowania admnistracyjnego) oraz możliwości przyczynienia się do wyższej świadomości i kultury prawnej ${ }^{51}$.

Istotą decyzji o pozwoleniu na budowę jest nabycie przez inwestora uprawnienia do wykonywania robót budowlanych wskazanych we wniosku o udzielenie pozwolenia na budowę. W związku z tym, przedmiotowa decyzja może

${ }^{47}$ Wyrok NSA z 17.05.1999 r., sygn. akt IV SA 747/97, LEX, nr 47285.

${ }^{48}$ B. Majchrzak, Procedura zgłoszenia robót budowlanych, Warszawa 2008, s. 69.

49 Z. Leoński. w: Z. Leoński, M. Szewczyk, Zasady prawa budowlanego i zagospodarowania przestrzennego, Bydgoszcz-Poznań 2002, s. 253.

${ }^{50}$ R. Dziwiński, P. Ziemski, Prawo budowlane. Komentarz, Dom Wydawniczy ABC, Warszawa 2005, s. 160.

${ }^{51}$ T. B. Babiel, Nadzór budowlany. Kompetencje organów administracji. Wzory. Akty prawne, Warszawa 2001, s. 74. 
być wydana wyłącznie w odniesieniu do planowanego zamierzenia inwestycyjnego. Niedopuszczalne jest prowadzenie postępowania w przypadku, gdy przedsięwzięcie budowlane jest $\mathrm{w}$ trakcie realizacji lub zostało już zrealizowane ${ }^{52}$, a to dlatego, że celem wydania decyzji o pozwoleniu na budowę nie może być legalizacja samowoli budowlanej. Realizacja robót budowlanych przed uzyskaniem ostatecznej decyzji o pozwoleniu na budowę powoduje bezprzedmiotowość postępowania administracyjnego wszczętego wnioskiem o pozwolenie na budowę. W związku z powyższym, w przedstawionej sytuacji postępowanie o udzielenie pozwolenia na budowę powinno zostać umorzone z mocy art. $105 \S 1$ Kodeksu postępowania administracyjnego ${ }^{53}$.

Tak jak w przypadku inwestycji objętych obowiązkiem dokonania zgłoszenia zamiaru wykonywania robót budowlanych, tak i przy wydawaniu decyzji o pozwoleniu na budowę - właściwym jest organ administracji architektoniczno-budowlanej. Co do zasady jest nim starosta, jako organ pierwszej instancji. Wojewoda jest natomiast organem wyższego stopnia w stosunku do starosty, a także jest właściwy w przedmiocie udzielenia - jako organ pierwszej instancji pozwolenia na budowę obiektów budowlanych, o których mowa w art. 82 ust. 3 prawa budowlanego ${ }^{54}$ i w $\S 1$ Rozporządzenia Rady Ministrów z dnia 25 listopada 2010 r. w sprawie obiektów i robót budowlanych, w sprawach których organem pierwszej instancji jest wojewoda ${ }^{55}$.

${ }^{52}$ Art. 32 ust. 4a prawa budowlanego - nie wydaje się pozwolenia na budowę w przypadku rozpoczęcia robót budowlanych z naruszeniem przepisu art. 28 ust. 1 - roboty budowlane można rozpocząć jedynie na podstawie ostatecznej decyzji o pozwoleniu na budowę (co do zasady).

${ }^{53}$ Wyrok NSA z 7.12.2005 r., sygn. akt II OSK 285/05, Lex nr 190995.

${ }^{54}$ Wojewoda jest organem administracji architektoniczno-budowlanej wyższego stopnia w stosunku do starosty oraz organem pierwszej instancji w sprawach obiektów i robót budowlanych: usytuowanych na terenie pasa technicznego, portów i przystani morskich, morskich wód wewnętrznych, morza terytorialnego i wyłącznej strefy ekonomicznej, a także na innych terenach przeznaczonych do utrzymania ruchu i transportu morskiego; hydrotechnicznych piętrzących, upustowych, regulacyjnych, melioracji podstawowych oraz kanałów i innych obiektów służących kształtowaniu zasobów wodnych i korzystaniu z nich, wraz z obiektami towarzyszącymi; dróg publicznych krajowych i wojewódzkich wraz z obiektami i urządzeniami służącymi do utrzymania tych dróg i transportu drogowego oraz sytuowanymi w granicach pasa drogowego sieciami uzbrojenia terenu - niezwiązanymi z użytkowaniem drogi, a w odniesieniu do dróg ekspresowych i autostrad - wraz z obiektami i urządzeniami obsługi podróżnych, pojazdów i przesyłek; usytuowanych na obszarze kolejowym; lotnisk cywilnych wraz z obiektami i urządzeniami towarzyszącymi; usytuowanych na terenach zamkniętych.

${ }^{55}$ Rozporządzenie Rady Ministrów z dnia 25 listopada 2010 r. w sprawie obiektów i robót budowlanych, w sprawach których organem pierwszej instancji jest wojewoda (Dz.U. z 2010 r., nr 235, poz. 1539). Wojewoda jest organem administracji architektoniczno-budowlanej pierwszej instancji w sprawach dotyczących następujących obiektów i robót budowlanych, innych niż wy- 
Postępowanie mające na celu uzyskanie przez inwestora zgody na przystąpienie do realizacji zamierzenia inwestycyjnego inicjuje złożony wniosek o pozwolenie na budowę. Urzędowy wzór wniosku o pozwolenie na budowę został zawarty w załączniku do rozporządzenia Ministra Infrastruktury z dnia 23 czerwca 2003 r. w sprawie wzorów: wniosku o pozwolenie na budowę, oświadczenia o posiadanym prawie do dysponowania nieruchomością na cele budowlane i decyzji o pozwoleniu na budowę ${ }^{56}$. Poprzez określenie wzoru wniosku, ograniczono możliwość stawiania przez organ administracji publicznej nieuzasadnionych żądań pod adresem inwestora, który wystąpił o uzyskanie pozwolenia na budowę.

Rozstrzygnięcie w przedmiocie pozwolenia na budowę następuje w formie decyzji administracyjnej. Decyzją tą zasadniczo jest albo decyzja o pozwoleniu na budowę, która umożliwia legalne przystąpienie do wykonywania robót budowlanych, albo decyzja o odmowie udzielenia pozwolenia na budowę.

Decyzja w przedmiocie pozwolenia na budowę powinna uwzględniać wymogi art. 107 Kodeksu postępowania administracyjnego ${ }^{57}$, a gdy jest to uzasadnione - również art. 36 ust. 1 prawa budowlanego ${ }^{58}$.

mienione w art. 82 ust. 3 ustawy z dnia 7.07.1994 r. - Prawo budowlane: metra wraz ze związanymi z nimi urządzeniami budowlanymi oraz sieciami uzbrojenia terenu, jeżeli konieczność ich budowy lub przebudowy wynika z budowy lub przebudowy metra; sieci uzbrojenia terenu sytuowanych poza pasem drogowym drogi krajowej lub wojewódzkiej, jeżeli konieczność ich budowy lub przebudowy wynika z budowy lub przebudowy tej drogi; drogowych obiektów inżynierskich sytuowanych w granicach pasa drogowego drogi krajowej lub wojewódzkiej, niezwiązanych z tymi drogami; dróg gminnych lub powiatowych, jeżeli konieczność ich budowy lub przebudowy wynika z budowy lub przebudowy drogi krajowej lub wojewódzkiej; zjazdów, w rozumieniu art. 4 pkt 8 ustawy z dnia 21.03.1985 r. o drogach publicznych, z dróg krajowych i wojewódzkich; sieci przesyłowych, w rozumieniu art. 3 pkt 11a ustawy z dnia 10.04.1997 r. - Prawo energetyczne; rurociągów przesyłowych dalekosiężnych służących do transportu ropy naftowej i produktów naftowych.

${ }^{56}$ Rozporządzenie Ministra Infrastruktury z dnia 23.06.2003 r. w sprawie wzorów: wniosku o pozwolenie na budowę, oświadczenia o posiadanym prawie do dysponowania nieruchomością na cele budowlane i decyzji o pozwoleniu na budowę (Dz.U. z 2003 r., nr 120, poz. 1127 z późn. zm.).

${ }^{57}$ Decyzja powinna zawierać: oznaczenie organu administracji publicznej, datę wydania, oznaczenie strony lub stron, powołanie podstawy prawnej, rozstrzygnięcie, uzasadnienie faktyczne i prawne, pouczenie, czy i w jakim trybie służy od niej odwołanie, podpis z podaniem imienia i nazwiska oraz stanowiska służbowego osoby upoważnionej do wydania decyzji lub, jeżeli decyzja wydana została w formie dokumentu elektronicznego, bezpieczny podpis elektroniczny weryfikowany za pomocą ważnego kwalifikowanego certyfikatu. Decyzja, w stosunku do której może być wniesione powództwo do sądu powszechnego lub skarga do sądu administracyjnego, powinna zawierać ponadto pouczenie o dopuszczalności wniesienia powództwa lub skargi.

${ }^{58} \mathrm{~W}$ decyzji o pozwoleniu na budowę właściwy organ, w razie potrzeby: określa szczególne warunki zabezpieczenia terenu budowy i prowadzenia robót budowlanych; określa czas użytkowania tymczasowych obiektów budowlanych; określa terminy rozbiórki a) istniejących obiektów 
Podkreślenia wymaga, że rozstrzygając w sprawie o pozwolenie na budowę, właściwy organ jest związany wnioskiem inwestora, atem w przypadku wątpliwości czy też braków wniosku powinien on wezwać inwestora do jego uzupełnienia bądź doprecyzowania. Organ administracji architektoniczno-budowlanej może udzielić pozwolenia na budowę albo odmówić jego wydania wyłącznie w granicach wniosku złożonego przez inwestora ${ }^{59}$.

\section{Użytkowanie obiektu budowlanego}

Zakończenie robót budowlanych wiąże się z koniecznością podjęcia różnych działań przez inwestora. Ustawodawca zdecydował się na odrębne uregulowania w tym zakresie w odniesieniu do robót budowlanych objętych obowiązkiem uzyskania pozwolenia na budowę. Obowiązek podjęcia przez inwestora stosownych działań może wynikać także z faktu stwierdzenia przez właściwy organ działań zakwalifikowanych jako samowola budowlana, a także z okoliczności planowania przystąpienia do użytkowania przed wykonaniem wszystkich robót budowlanych ${ }^{60}$.

Do użytkowania obiektu budowlanego, na którego wzniesienie wymagane jest pozwolenie na budowę, można przystąpić po zawiadomieniu właściwego organu o zakończeniu budowy. Oznacza to, że budowa obiektu budowlanego zrealizowana na podstawie przedmiotowej decyzji winna zakończyć się skierowaniem stosownego zawiadomienia do właściwego organu administracji publicznej. Wymogu takiego ustawodawca nie wprowadził w odniesieniu do pozostałych kategorii robót budowlanych, a więc prac polegających na przebudowie, montażu, remoncie lub rozbiórce obiektu budowlanego. W związku z powyższym, do użytkowania przebudowanego lub wyremontowanego obiektu budowlanego można przystąpić bez konieczności dokonania zawiadomienia o zakończeniu robót budowlanych, przy czym dotyczy to również sytuacji, gdy prowadzenie robót wymagało uzyskania pozwolenia na budowę ${ }^{61}$.

budowlanych nieprzewidzianych do dalszego użytkowania, b) tymczasowych obiektów budowlanych; określa szczegółowe wymagania dotyczące nadzoru na budowie; zamieszcza informację o obowiązkach i warunkach, wynikających z art. 54 lub art. 55.

${ }^{59}$ Wyrok WSA w Krakowie z 6.03.2008 r., sygn. akt II SA/Kr 587/07, Lex 487252.

${ }^{60}$ K. Małysa-Sulińska, Administracyjnoprawne..., s. 231.

${ }^{61}$ R. Godlewski, w: Prawo budowlane z umowami w działalności inwestycyjnej. Komentarz, red. H. Kisilowska, Warszawa 2010, s. 262. 
Ustawodawca wprowadził również wyjątek od zasady - wymóg uzyskania pozwolenia na użytkowanie obiektu budowlanego. Zgodnie z art. 55 pkt 1 prawa budowlanego przed przystąpieniem do użytkowania obiektu budowlanego należy uzyskać ostateczną decyzję o pozwoleniu na użytkowanie, jeżeli na jego wzniesienie jest wymagane pozwolenie na budowę i jest on zaliczony do jednej z następujących kategorii obiektów budowlanych: V, IX-XVIII, XX, XXII, XXIV, XXVII-XXX ${ }^{62}$. Uzyskanie pozwolenia na użytkowanie jest wymagane również wówczas, gdy w postępowaniu mającym na celu legalizację samowoli budowlanej zatwierdzono projekt budowlany, a także gdy przystąpienie do użytkowania obiektu budowlanego ma nastąpić przed wykonaniem wszystkich robót budowlanych.

Złożenie przez inwestora zawiadomienia o zakończeniu budowy jest równoznaczne z chęcią przystąpienia do użytkowania obiektu. Zawiadomienie inicjuje jeden z trybów, które mogą być uruchomione po zakończeniu robót budowlanych, a przed przystąpieniem do użytkowania obiektu. Jego przedmiotem jest

${ }^{62}$ Obiekty sportu i rekreacji, jak: stadiony, amfiteatry, skocznie i wyciągi narciarskie, kolejki linowe, odkryte baseny, zjeżdżalnie; budynki kultury, nauki i oświaty, jak: teatry, opery, kina, muzea, galerie sztuki, biblioteki, archiwa, domy kultury, budynki szkolne i przedszkolne, żłobki, kluby dziecięce, internaty, bursy i domy studenckie, laboratoria i placówki badawcze, stacje meteorologiczne i hydrologiczne, obserwatoria, budynki ogrodów zoologicznych i botanicznych; budynki kultu religijnego, jak: kościoły, kaplice, klasztory, cerkwie, zbory, synagogi, meczety oraz domy pogrzebowe, krematoria; budynki służby zdrowia, opieki społecznej i socjalnej, jak: szpitale, sanatoria, hospicja, przychodnie, poradnie, stacje krwiodawstwa, lecznice weterynaryjne, domy pomocy i opieki społecznej, domy dziecka, domy rencisty, schroniska dla bezdomnych oraz hotele robotnicze; budynki administracji publicznej, budynki Sejmu, Senatu, Kancelarii Prezydenta, ministerstw i urzędów centralnych, terenowej administracji rządowej i samorządowej, sądów i trybunałów, więzień i domów poprawczych, zakładów dla nieletnich, zakładów karnych, aresztów śledczych oraz obiekty budowlane Sił Zbrojnych; budynki zakwaterowania turystycznego i rekreacyjnego, jak: hotele, motele, pensjonaty, domy wypoczynkowe, schroniska turystyczne; budynki sportu i rekreacji, jak: hale sportowe i widowiskowe, kryte baseny; budynki biurowe i konferencyjne; budynki handlu, gastronomii i usług, jak: sklepy, centra handlowe, domy towarowe, hale targowe, restauracje, bary, kasyna, dyskoteki, warsztaty rzemieślnicze, stacje obsługi pojazdów, myjnie samochodowe, garaże powyżej dwóch stanowisk, budynki dworcowe; budynki przemysłowe, jak: budynki produkcyjne, służące energetyce, montownie, wytwórnie, rzeźnie oraz obiekty magazynowe, jak: budynki składowe, chłodnie, hangary, wiaty, a także budynki kolejowe, jak: nastawnie, podstacje trakcyjne, lokomotywownie, wagonownie, strażnice przejazdowe, myjnie taboru kolejowego; stacje paliw; place składowe, postojowe, składowiska odpadów, parkingi; obiekty gospodarki wodnej, jak: zbiorniki wodne i nadpoziomowe, stawy rybne; budowle hydrotechniczne piętrzące, upustowe i regulacyjne, jak: zapory, progi i stopnie wodne, jazy, bramy przeciwpowodziowe, śluzy wałowe, syfony, wały przeciwpowodziowe, kanały, śluzy żeglowne, opaski i ostrogi brzegowe, rowy melioracyjne; drogowe i kolejowe obiekty mostowe, jak: mosty, estakady, kładki, przejścia podziemne, wiadukty, przepusty, tunele; wolno stojące kominy i maszty; obiekty służące do korzystania z zasobów wodnych, jak: ujęcia wód morskich i śródlądowych, budowle zrzutów wód i ścieków, pompownie, stacje strefowe, stacje uzdatniania wody, oczyszczalnie ścieków. 
weryfikacja złożonej przez inwestora dokumentacji przeprowadzonych robót, a także ocena, czy z technicznego punktu widzenia możliwe jest przystąpienie do użytkowania obiektu budowlanego.

W tym „uproszczonym” postępowaniu rozstrzygnięcie zasadniczo nie przybiera postaci decyzji administracyjnej. Pozytywne rozstrzygnięcie dla inwestora stanowi „milcząca akceptacja” właściwego organu. Do przedmiotowego postępowania - podobnie jak w przypadku trybu uruchamianego zgłoszeniem przez inwestora zamiaru wykonywania robót budowlanych - nie mają w pełni zastosowania przepisy Kodeksu postępowania administracyjnego ${ }^{63}$.

Zawiadomienie o zakończeniu budowy obiektu budowlanego inwestor powinien złożyć co najmniej 21 dni przed zamierzonym terminem przystąpienia do użytkowania. Do użytkowania obiektu budowlanego objętego obowiązkiem dokonania zawiadomienia o zakończeniu budowy można bowiem przystąpić, jeżeli w terminie 21 dni od dnia doręczenia zawiadomienia właściwemu organowi nie zgłosi on sprzeciwu w drodze decyzji ${ }^{64}$.

Oceny prawidłowości i kompletności dokumentów złożonych z zawiadomieniem o zakończeniu budowy dokonuje właściwy organ nadzoru budowlanego. Organ może na podstawie art. 57 ust. 4 prawa budowlanego żądać uzupełnienia dokumentów, które $\mathrm{w}$ wyniku ich sprawdzenia pod kątem zgodności z obowiązującymi przepisami oraz przydatności jako materiału dowodowego okazały się niekompletne lub z brakami i nieścisłościami. Ustawodawca enumeratywnie wyliczył dokumenty ${ }^{65}$, które należy dołączyć do zawiadomienia o zakończeniu budowy, a w związku z tym brak jest podstaw prawnych uzasadniających wezwanie inwestora do przedłożenia jakichkolwiek materiałów, które nie zostały wymienione w art. 57 prawa budowlanego.

Sprzeciw stanowi jeden z możliwych sposobów załatwienia sprawy administracyjnej wszczętej zawiadomieniem o zakończeniu budowy. Oznacza on zakaz

${ }^{63}$ K. Małysa-Sulińska, Administracyjnoprawne..., s. 233.

${ }^{64}$ Art. 54 prawa budowlanego.

${ }^{65}$ Do zawiadomienia należy dołączyć wymagane załączniki, a mianowicie: oryginał dziennika budowy, oświadczenie kierownika budowy, oświadczenie o właściwym zagospodarowaniu terenów przyległych, protokoły badań i sprawdzeń, inwentaryzację geodezyjną powykonawczą, potwierdzenie odbioru wykonanych przyłączy, kopię świadectwa charakterystyki energetycznej budynku, wynik audytu bezpieczeństwa ruchu drogowego oraz - w przypadku nieuwzględnienia przez zarządcę drogi wyniku tego audytu - uzasadnienie zarządcy drogi stanowiące załącznik do wyniku audytu, kopię rysunków wchodzących w skład zatwierdzonego projektu budowlanego z naniesionymi zmianami i uzupełniającym opisem zmian, przy czym nie w każdym przypadku należy składać wszystkie wskazane powyżej dokumenty. 
przystąpienia do użytkowania obiektu budowlanego objętego wskazanym zawiadomieniem. Właściwą formą wniesienia sprzeciwu, o którym mowa w art. 54 prawa budowlanego, jest decyzja administracyjna. Organ nadzoru budowlanego powinien wnieść sprzeciw dotyczący przystąpienia do użytkowania obiektu budowlanego, gdy w określonym terminie inwestor nie dołączył do zawiadomienia o zakończeniu budowy żądanych przez organ dokumentów lub nie usunął wskazanych nieścisłości w przedłożonych materiałach. Wniesienie sprzeciwu może być także skutkiem dokonania przez organ ustalenia, że obiekt budowlany został wykonany z naruszeniem warunków określonych w pozwoleniu na budowę.

Jak już wcześniej wspomniano, przystąpienie do użytkowania obiektu budowlanego w określonych przypadkach może być uzależnione od uprzedniego uzyskania pozwolenia na użytkowanie. Postępowanie w tym zakresie inicjuje wniosek inwestora, który należy złożyć po zakończeniu robót budowlanych. Przedmiotem postępowania w zakresie pozwolenia na użytkowanie jest sprawdzenie, czy obiekt budowlany został wykonany zgodnie z zatwierdzonym projektem budowlanym i warunkami pozwolenia na budowę. Przedmiotowe postępowanie w odróżnieniu od procedury inicjowanej złożeniem zawiadomienia o zakończeniu budowy obiektu budowlanego wiąże się z przeprowadzeniem kontroli budowy.

Dość precyzyjnie ustawodawca określił również obowiązki związane z użytkowaniem obiektu budowlanego. Wśród wynikających wprost z przepisów ustawy - Prawo budowlane obowiązków związanych z użytkowaniem obiektu budowlanego wymienić należy: obowiązek przechowywania i udostępniania dokumentacji obiektu budowlanego, obowiązek właściwego utrzymywania lub użytkowania obiektu budowlanego, obowiązek przeprowadzania kontroli stanu obiektu budowlanego, obowiązek wykonywania napraw określonych w przepisach odrębnych lub umowach.

Właściwy organ w razie stwierdzenia, że obiekt budowlany jest w nieodpowiednim stanie technicznym, powoduje swym wyglądem oszpecenie otoczenia albo jest użytkowany niezgodnie z przeznaczeniem bądź w sposób zagrażający życiu lub zdrowiu ludzi, środowisku lub bezpieczeństwu mienia, wydaje decyzję nakazującą usunięcie stwierdzonych nieprawidłowości. Do środków władczej ingerencji właściwego organu należy także wydawanie nakazów rozbiórki i uporządkowania terenu, gdy nieużytkowany lub niewykończony obiekt nie nadaje się do remontu, odbudowy lub wykończenia; wydawanie nakazów opróżnienia w całości lub części przeznaczonego na pobyt ludzi budynku bezpośrednio grożącego zawaleniem lub wyłączenia takiego budynku z użytkowania; zarządzenie umieszczenia na budynku 
zawiadomienia o stanie zagrożenia i zarządzenie wykonania doraźnych zabezpieczeń i usunięcie zagrożenia bezpieczeństwa ludzi i mienia, z określeniem terminów ich wykonania, zapewnienie w razie konieczności niezwłocznego podjęcia działań mających na celu usunięcie niebezpieczeństwa - na koszt właściciela lub zarządcy - oraz zastosowania niezbędnych środków zabezpieczających ${ }^{66}$.

Naruszenie obowiązku właściwego utrzymywania lub użytkowania obiektu budowlanego zagrożone jest karą. Ten, kto nie spełnia obowiązku utrzymania obiektu budowlanego w należytym stanie technicznym, użytkuje obiekt w sposób niezgodny z przepisami lub nie zapewnia bezpieczeństwa użytkowania obiektu budowlanego, podlega grzywnie nie mniejszej niż 100 stawek dziennych, karze ograniczenia wolności albo pozbawienia wolności do roku ${ }^{67}$.

\section{Zmiana sposobu użytkowania obiektu budowlanego lub jego części}

Przez zmianę sposobu użytkowania obiektu budowlanego lub jego części - zgodnie z art. 71 ust. 1 pkt 2 prawa budowlanego - należy rozumieć w szczególności podjęcie bądź zaniechanie w obiekcie budowlanym lub jego części działalności zmieniającej warunki: bezpieczeństwa pożarowego, powodziowego, pracy, zdrowotne, higieniczno-sanitarne, ochrony środowiska bądź wielkość lub układ obciążeń. Ustawodawca w wyniku użycia w art. 71 ust. 1 zwrotu ,rozumie się w szczególności", nie zawarł w tym przepisie wyczerpującej definicji pojęcia zmiany sposobu użytkowania obiektu budowlanego lub jego części, ograniczając się jedynie do wskazania najbardziej powszechnych przykładów tej zmiany. Zmiana sposobu użytkowania obiektu lub jego części sprowadza się zatem głównie do potrzeby ustalenia, czy i w jakim stopniu podjęcie lub zaniechanie w obiekcie budowlanym lub jego części działalności związanej z jego użytkowaniem wpływa na zmianę wymagań stawianych obiektowi, związanych głównie z bezpieczeństwem jego dalszego, zmienionego sposobu użytkowania ${ }^{68}$.

Przez zmianę sposobu użytkowania obiektu budowlanego należy więc rozumieć nie tylko przeznaczenie obiektu lub jego części do innego rodzaju użytkowania, lecz także zintensyfikowanie dotychczasowego sposobu jego użytkowania, jeżeli wywołuje to skutki określone w art. 71 prawa budowlanego. Zwiększenie

\footnotetext{
${ }^{66}$ M. Stahl, w: Materialne..., s. 362-363.

${ }^{67}$ Art. 91a prawa budowlanego.

${ }^{68}$ Wyrok NSA z 13.09.2006 r., sygn. akt II OSK 1064/05, Lex nr 320885.
} 
realizowanej w obiekcie budowlanym lub jego części działalności wytwórczej lub usługowej może spowodować niekorzystne dla otoczenia skutki ${ }^{69}$.

Należy stwierdzić, iż każde podjęcie bądź zaniechanie działalności w obiekcie budowlanym lub jego części, powodujące skutki o charakterze wskazanym w art. 71 ust. 1 prawa budowlanego, należy kwalifikować jako zmianę sposobu użytkowania obiektu budowlanego lub jego części, przy czym zmiana sposobu użytkowania obiektu budowlanego lub jego części może polegać też na działaniu, które nie wiąże się z wykonywaniem robót budowlanych. Oznacza to, że nie każda zmiana działalności w obiekcie budowlanym lub jego części jest prawnie istotna, ale tylko taka, która wpływa na zmianę wymagań stawianych obiektowi, związanych głównie z bezpieczeństwem jego sposobu użytkowania.

Zasadą jest, że zmiana sposobu użytkowania obiektu budowlanego lub jego części wymaga dokonania zgłoszenia zmiany sposobu użytkowania. Jeżeli jednak zamierzona zmiana sposobu użytkowania wymaga wykonania robót budowlanych objętych obowiązkiem uzyskania pozwolenia na budowę, rozstrzygnięcie $\mathrm{w}$ tej sprawie następuje $\mathrm{w}$ decyzji o pozwoleniu na budowę ${ }^{70}$. Jeśli zaś planowana zmiana sposobu użytkowania wymaga wykonania robót budowlanych objętych obowiązkiem zgłoszenia zamiaru wykonywania robót budowlanych - do zgłoszenia zmiany sposobu użytkowania obiektu budowlanego lub jego części stosuje się odpowiednio przepisy art. 30 ust. 2-4 prawa budowlanego ${ }^{71}$.

Zgłoszenie zamiaru dokonania zmiany sposobu użytkowania obiektu inicjuje postępowanie, które nie kończy się wydaniem decyzji administracyjnej. Pozytywne rozstrzygnięcie stanowi „milcząca akceptacja” właściwego organu administracji publicznej. Postępowanie jest więc „uproszczone”, do którego nie mają w pełni zastosowania przepisy Kodeksu postępowania administracyjnego.

Zgłoszenie zamiaru zmiany sposobu użytkowania obiektu budowlanego lub jego części powinno nastąpić przed planowanym terminem dokonania tej zmiany. We wskazanym w art. 71 ust. 4 prawa budowlanego 30-dniowym terminie właściwy organ administracji architektoniczno-budowlanej może bowiem wnieść sprzeciw dotyczący dokonania zmiany sposobu użytkowania obiektu budowlanego lub jego części. W zgłoszeniu należy określić dotychczasowy i zamierzony sposób użytkowania obiektu budowlanego lub jego części ${ }^{72}$.

\footnotetext{
${ }^{69}$ Wyrok WSA w Warszawie z 29.06.2005 r., sygn. akt VII SA/Wa 476/05, Lex nr 179074.

${ }^{70}$ Art. 71 ust. 6 pkt 1 prawa budowlanego.

${ }^{71}$ Art. 71 ust. 6 pkt 2 prawa budowlanego.

${ }^{72}$ Art. 71 ust. 2 zdanie drugie prawa budowlanego.
} 
Organ administracji architektoniczno-budowlanej ocenia, czy dokumenty przedstawione przez zgłaszającego są wystarczające na potrzeby dokonania prawidłowego zgłoszenia zamiaru zmiany sposobu użytkowania obiektu budowlanego lub jego części. W związku z tym sprawdzana jest zarówno kompletność przedłożonych materiałów, jak i dokonywana jest ich ocena jako materiału dowodowego, w oparciu o który ma zapaść rozstrzygnięcie w sprawie.

Rozstrzygnięcie jest wydawane wyłącznie wówczas, gdy właściwy organ administracji architektoniczno-budowlanej nie wyraża zgody na dokonanie zmiany sposobu użytkowania obiektu budowlanego lub jego części, przy czym podstawy sprzeciwu organu mogą być różne w tym zakresie ${ }^{73}$.

Zgoda organu na dokonanie zmiany sposobu użytkowania obiektu budowlanego lub jego części zasadniczo nie przybiera formy aktu administracyjnego. Zmiany sposobu użytkowania obiektu budowlanego lub jego części można dokonać po upływie 30-dniowego terminu wskazanego w art. 71 ust. 4 prawa budowlanego, z zastrzeżeniem, że w tym terminie właściwy organ administracji architektoniczno-budowlanej nie doręczył zgłaszającemu sprzeciwu. Przepisy nie wskazują takiej możliwości - jednak dopuszczalne jest dokonanie zmiany sposobu użytkowania obiektu budowlanego lub jego części przed upływem 30-dniowego terminu, o którym mowa w art. 71 ust. 4 prawa budowlanego. Możliwość taka zachodzi, gdy właściwy organ administracji architektoniczno-budowlanej poinformował zgłaszającego o braku sprzeciwu wobec objętej przedmiotowym zgłoszeniem zmiany sposobu użytkowania.

\section{Rozbiórka obiektu budowlanego}

W pojęciu robót budowlanych zawiera się również rozbiórka obiektu budowlanego. Oznacza to, że w odniesieniu do robót budowlanych polegających na rozbiórce zastosowanie ma zasada wyrażona w art. 28 ust. 1 prawa budowlanego,

${ }^{73}$ Sprzeciw jest wnoszony w przypadku, gdy mimo nałożenia takiego obowiązku nie uzupełniono zgłoszenia zamiaru zmiany sposobu użytkowania obiektu budowlanego lub jego części; gdy zamierzona zmiana sposobu użytkowania obiektu budowlanego lub jego części: wymaga wykonania robót budowlanych, objętych obowiązkiem uzyskania pozwolenia na budowę; narusza ustalenia obowiązującego miejscowego planu zagospodarowania przestrzennego albo decyzji o warunkach budowy i zagospodarowania terenu; może spowodować niedopuszczalne zagrożenie bezpieczeństwa ludzi lub mienia; może spowodować niedopuszczalne pogorszenie stanu środowiska lub stanu zachowania zabytków; może spowodować niedopuszczalne pogorszenie warunków zdrowotno-sanitarnych; może spowodować niedopuszczalne wprowadzenie, utrwalenie bądź zwiększenie ograniczeń lub uciążliwości dla terenów sąsiednich. 
zgodnie z którą roboty mogą być prowadzone na podstawie ostatecznej decyzji zezwalającej na ich prowadzenie. Ustawodawca wprowadził jednak odstępstwa od tej zasady, wskazując - w art. 31 ust. 1 prawa budowlanego - obiekty i urządzenia budowlane ${ }^{74}$, których rozbiórka nie wymaga uzyskania pozwolenia na rozbiórkę. Regulacja zawarta w art. 31 ust. 1 prawa budowlanego ma charakter katalogu zamkniętego i niedopuszczalne jest stosowanie w tym zakresie wykładni rozszerzającej ${ }^{75}$.

Pozwolenie na rozbiórkę nie stanowi jedynego przejawu reglamentacji możliwości przystąpienia do wykonywania robót budowlanych polegających na rozbiórce. Część robót budowlanych zwolnionych od obowiązku uzyskania pozwolenia na rozbiórkę została objęta obowiązkiem dokonania zgłoszenia zamiaru ich wykonywania. Rozbiórka obiektów budowlanych wskazanych w art. 31 ust. 1 pkt 1 prawa budowlanego powinna zostać poprzedzona dokonaniem odpowiedniego zgłoszenia właściwemu organowi administracji publicznej. Ustawodawca zdecydował o poddaniu rozbiórki reglamentacji administracyjnej w uproszczonej, bo niewymagającej wydania decyzji administracyjnej, formie niewpisanych do rejestru zabytków oraz nieobjętych ochroną konserwatorską budynków i budowli o wysokości poniżej $8 \mathrm{~m}$, jeżeli ich odległość od granicy działki jest nie mniejsza niż połowa wysokości.

Rozbiórka obiektów i urządzeń budowlanych wskazanych w art. 31 ust. 1 pkt 2 prawa budowlanego nie została poddana ani obowiązkowi uzyskania pozwolenia na rozbiórkę, ani obowiązkowi dokonania zgłoszenia. Spod reglamentacji administracyjnej została wyłączona rozbiórka obiektów i urządzeń budowlanych, na których budowę nie jest wymagane pozwolenie, jeżeli nie podlegają ochronie jako zabytki.

Postępowanie po zgłoszeniu zamiaru wykonywania robót budowlanych polegających na rozbiórce nie wymaga wydania decyzji administracyjnej, a pozytywne rozstrzygnięcie dla wnioskodawcy stanowi „milcząca akceptacja” właściwego organu. W związku z powyższym, a także z uwagi na okoliczność, że do przedmiotowego postępowania nie mają w pełni zastosowania przepisy kodeksu postępowania administracyjnego, postępowanie w sprawie zgłoszenia zamiaru wykonywania robót budowlanych polegających na rozbiórce określa się mianem ,uproszczonego".

${ }^{74}$ Przez urządzenia budowlane należy rozumieć urządzenia techniczne związane z obiektem budowlanym, zapewniające możliwość użytkowania obiektu zgodnie z jego przeznaczeniem, jak przyłącza i urządzenia instalacyjne, w tym służące oczyszczaniu lub gromadzeniu ścieków, a także przejazdy, ogrodzenia, place postojowe i place pod śmietniki.

${ }^{75}$ Wyrok WSA w Krakowie z 29.08.2008 r., sygn. akt II SA/Kr 547/08, Lex 518844. 
W zgłoszeniu zamiaru wykonywania robót rozbiórkowych należy określić wyłącznie rodzaj, zakres i sposób wykonywania tych robót ${ }^{76}$. W związku z tym należy przyjąć, iż konieczne jest zaznaczenie zakresu planowanych robót rozbiórkowych na mapie, z której można odczytać odległość obiektu przeznaczonego do rozbiórki od granic działki, a także określenie wysokości obiektu objętego przedmiotowym zgłoszeniem. W określonych przypadkach może również istnieć potrzeba przedłożenia odpowiednich szkiców lub rysunków, z których wynika, jaka część obiektu została przeznaczona do rozbiórki.

Zgłaszający zamiar dokonania rozbiórki może zostać zobligowany do uszczegółowienia przedłożonej dokumentacji. Organ właściwy w przedmiocie przyjęcia zgłoszenia zamiaru dokonania rozbiórki może z uwagi na bezpieczeństwo ludzi lub mienia zobowiązać zgłaszającego do przedstawienia szczegółowych danych o obiekcie budowlanym, jak również informacji dotyczących prowadzenia robót rozbiórkowych ${ }^{77}$.

Sprzeciw organu wniesiony w związku z dokonaniem zgłoszenia zamiaru wykonywania robót rozbiórkowych jest równoznaczny z brakiem możliwości legalnego rozpoczęcia rozbiórki. Organ administracji architektoniczno-budowlanej wyraża w ten sposób brak zgody na rozpoczęcie robót rozbiórkowych objętych zgłoszeniem. Rozstrzygnięcie to przybiera formę decyzji administracyjnej.

Podstawę do wniesienia sprzeciwu dotyczącego przystąpienia do wykonywania robót rozbiórkowych może stanowić niedopełnienie obowiązku uzupełnienia przedmiotowego zgłoszenia. Sprzeciw może być wniesiony również wówczas, gdy zgłaszający dokonał błędnej kwalifikacji robót budowlanych jako nieobjętych obowiązkiem uzyskania pozwolenia na rozbiórkę ${ }^{78}$ lub gdy rozbiórka objęta zgłoszeniem narusza ustalenia miejscowego planu zagospodarowania przestrzennego lub inne przepisy ${ }^{79}$. Skuteczne wniesienie sprzeciwu wobec przystąpienia do wykonywania robót rozbiórkowych może nastąpić wyłącznie w zakreślonym przez ustawodawcę 30-dniowym terminie.

Decyzja zezwalająca na prowadzenie robót rozbiórkowych kończy postępowanie jurysdykcyjne, w trakcie którego dokonuje się oceny, czy w konkretnym przypadku dopuszczalne jest podjęcie rozbiórki. Pozwolenie na rozbiórkę zalicza się do kategorii pozwoleń budowlanych. Zgodnie z art. 3 pkt 12 prawa budow-

\footnotetext{
${ }^{76}$ Art. 31 ust. 2 zdanie pierwsze prawa budowlanego.

${ }^{77}$ Art. 31 ust. 4 prawa budowlanego.

${ }^{78}$ Art. 30 ust. 6 pkt 1 prawa budowlanego.

${ }^{79}$ Art. 30 ust. 6 pkt 2 prawa budowlanego.
} 
lanego przez pojęcie pozwolenia na budowę należy rozumieć decyzję administracyjną zezwalającą na rozpoczęcie i prowadzenie budowy lub wykonywanie robót budowlanych innych niż budowa obiektu budowlanego, czyli - zgodnie $\mathrm{z}$ art. 3 pkt 7 - również prac polegających na rozbiórce. Oznacza to, że do pozwolenia na rozbiórkę należy stosować przepisy, w których ustawodawca posługuje się terminem „pozwolenie na budowę”, z zastrzeżeniem, że dana materia nie została uregulowana przepisem szczególnym odnoszącym się wyłącznie do pozwolenia na rozbiórkę ${ }^{80}$.

Obligatoryjnymi załącznikami wniosku o pozwolenie na rozbiórkę obiektu budowlanego są: zgoda właściciela obiektu; szkic usytuowania obiektu budowlanego; opis zakresu i sposobu prowadzenia robót rozbiórkowych; opis sposobu zapewnienia bezpieczeństwa ludzi i mienia; pozwolenia, uzgodnienia lub opinie innych organów, a także inne dokumenty wymagane przepisami szczególnymi. Do wniosku o pozwolenie na rozbiórkę obiektu budowlanego należy dołączyć również, jeśli istnieje taka potrzeba, projekt rozbiórki obiektu ${ }^{81}$.

Decyzją o pozwoleniu na budowę następuje wyrażenie zgody na rozpoczęcie wnioskowanych robót rozbiórkowych, przy czym rozstrzygnięcie to może być wydane tylko wówczas, gdy spełnione zostały wszystkie wymagania związane zjego udzieleniem określone przez przepisy ustawy z dnia 7 lipca 1994 r. - Prawo budowlane. Decyzja ta, uwzględniając specyfikę przedmiotu rozstrzygnięcia, powinna odpowiadać wymogom, jakie przepisy stawiają wobec pozwolenia budowlanego.

\section{Podsumowanie}

Warunkiem niezbędnym legalnego prowadzenia procesu inwestycyjnego jest uzyskanie zgody właściwego organu administracji architektoniczno-budowlanej na realizację zaplanowanej inwestycji. Zasadą wynikającą z ustawy z 7 lipca 1994 roku - Prawo budowlane jest, że roboty budowlane można prowadzić na podstawie ostatecznej decyzji o pozwoleniu na budowę. Wyjątki od tej zasady przewidują konkretne przepisy ustawy, określające katalog zamknięty obiektów budowlanych i robót budowlanych, których wykonanie co prawda nie musi poprzedzać uzyskanie pozwolenia na budowę, natomiast konieczne jest zgłoszenie zamiaru ich wykonania.

\footnotetext{
${ }^{80}$ K. Małysa-Sulińska, Administracyjnoprawne..., s. 296-297.

${ }^{81}$ Art. 33 ust. 4 prawa budowlanego.
} 
W artykule przedstawiono pewne zasady prowadzenia postępowania, zmierzającego do wykonywania określonych robót budowlanych.

Stan polskiego prawa inwestycyjno-budowlanego od lat budzi krytykę. Jednak inwestorzy powinni rozumieć wymogi zrównoważonego rozwoju i wynikające stąd ograniczenia. Ład przestrzenny, ochrona środowiska, zabytków, a także walory estetyczne przestrzeni to walory, które muszą być poddane szczególnej ochronie. Natomiast wyznaczenie zakresu ochrony tych wartości to zadanie państwa. Polityka w tym zakresie musi być sprecyzowana, a jednocześnie musi posiadać postać normy prawnej, aby inwestor wiedział, jakie podejmować czynności przy prowadzeniu określonych prac. Dlatego też ogromne znaczenie mają przepisy prawa regulujące proces inwestycyjny.

Oczywiście obecnie obowiązujące uregulowania nie są idealne, jednakże ewentualne zmiany nie powinny abstrahować od dotychczasowych doświadczeń. Diagnoza aktualnych unormowań powinna być punktem wyjścia do projektowania przyszłych rozwiązań prawnych. Niniejsze opracowanie ma na celu przybliżenie zasad obowiązujących w uregulowaniach prawnych dotyczących procesu inwestycyjnego.

\section{Literatura}

Aspekty prawne planowania i zagospodarowania przestrzennego, red. W. Szwajdler, Warszawa 2013.

Babiel T.B., Nadzór budowlany. Kompetencje organów administracji. Wzory. Akty prawne, Warszawa 2001.

Dziwiński R., Ziemski P., Prawo budowlane. Komentarz, Warszawa 2005.

Kwaśniak P., Plan miejscowy w systemie zagospodarowania przestrzennego, wyd. 3, Warszawa 2011.

Leoński Z., Szewczyk M., Zasady prawa budowlanego i zagospodarowania przestrzennego, Bydgoszcz-Poznań 2002.

Majchrzak B., Procedura zgłoszenia robót budowlanych, Warszawa 2008.

Małysa-Sulińska K., Administracyjnoprawne aspekty inwestycji budowlanych, Warszawa 2012.

Materialne prawo administracyjne. Pojęcia, instytucje, zasady, red. M. Stahl, wyd. 2, Warszawa 2005.

Niewiadomski Z., Planowanie przestrzenne. Zarys systemu, wyd. 2, Warszawa 2003.

Niewiadomski Z., Nowe prawo o planowaniu i zagospodarowaniu przestrzennym, Warszawa 2003. 
Prawo budowlane z umowami $w$ działalności inwestycyjnej. Komentarz, red. H. Kisilowska, Warszawa 2010.

Przestrzeń i nieruchomości jako przedmiot prawa administracyjnego. Publiczne prawo rzeczowe, red. I. Niżnik-Dobosz, Warszawa 2012.

Słownik wyrazów obcych PWN, red. J. Tokarski, Warszawa 1980.

Sypniewski D., Nadzór nad procesem budowlanym, Warszawa 2011.

Uniwersalny słownik języka polskiego, red. S. Dubisz, Warszawa 2003.

Ustawa o planowaniu i zagospodarowaniu przestrzennym. Komentarz, red. Z. Niewiadomski, Warszawa 2004.

Ustawa o planowaniu i zagospodarowaniu przestrzennym, przepisy - omówienia - komentarze, red. G. Buczek, M. Tetera-Jankowska, Warszawa 2003.

Weiss I., Jurga R., Inwestycje budowlane, Warszawa 2005.

\section{Orzecznictwo}

Wyrok SN z 22.02.2002 r., sygn. akt III RN 203/2000, OSNP 2001, nr 20, poz. 606.

Wyrok NSA z 17.05.1999 r., sygn. akt IV SA 747/97, LEX, nr 47285.

Wyrok NSA-OZ w Krakowie z 10.10.2000 r., sygn. akt II SA/Kr 1010/00, ONSA 2001, nr 4.

Wyrok NSA z 17.11.2005 r., sygn. akt II OSK 197/05, Lex nr 196647.

Wyrok NSA z 7.12.2005 r., sygn. akt II OSK 285/05, Lex nr 190995.

Wyrok NSA z 13.09.2006 r., sygn. akt II OSK 1064/05, Lex nr 320885.

Wyrok NSA z 26.01.2007 r., sygn. akt II OSK 239/06, LexPolonica nr 2118120.

Wyrok NSA z 17.04.2007 r., sygn. akt II OSK 646/06, LexPolonica nr 2118199.

Wyrok NSA z 12.05.2011 r., sygn. akt II OSK 355/11, CBOSA.

Wyrok NSA z 19.01.2012 r., sygn. akt II OSK 2373/11, CBOSA.

Wyrok WSA w Warszawie z 29.06.2005 r., sygn. akt VII SA/Wa 476/05, Lex nr 179074.

Wyrok WSA w Krakowie z 29.08.2008 r., sygn. akt II SA/Kr 547/08, Lex 518844.

Wyrok WSA w Krakowie z 21.12.2010 r., sygn. akt II SA/Kr 1171/10, Lex nr 753446. 
INVESTMENT-BUILDING PROCESS ACCORDING ADMINISTRATIVE

\begin{abstract}
Summary
The investment and construction activity is generally governed by administrative provisions, as within the construction process administrative and legal procedures are of utmost importance. Provisions of multiple normative acts are applicable to issues related to construction investments. They include both issues, the subject of which is the investment-related field, and such which are applicable not only to investments in construction. The building law states the necessity of exertion of specific conduct within the construction process.

This paper presents human limitations investment activities given in a set of legal acts regulating investment and construction activity which can be undertaken at certain stages of the construction process. Implementation of construction projects is possible only in the area of a specific purpose. According to this, first issue described related to the intended use of land for investment. Next, the issues related to consent to undertake works has been discussed, as well as the use of the works, the changes in the works and its demolition.
\end{abstract}

Translated by Magdalena Łuczak

Keywords: investment-building process, construction works, investment and construction process 